\title{
Jan Socha (red.), „Z kochania się rodzi. Uniwersytety ludowe - przeszłość i teraźniejszość", Oficyna Wydawnicza Stopka, Warszawa-Łomża 2013
}

Wspólnym wysiłkiem trzech podmiotów: Towarzystwa Uniwersytetów Ludowych, Fundacji Polskich Uniwersytetów Ludowych w Warszawie oraz łomżyńskiej Oficyny Wydawniczej „Stopka”, w ramach serii wydawniczej „Biblioteka Uniwersytetów Ludowych”, ukazała się książka „pisana w okresie minionych 20 lat przez wielu ludzi zakochanych w uniwersytetach ludowych, przez ich znawców, działaczy i sympatyków" (Słowo wstępne, s. 5). Składają się nań w przeważającej mierze artykuły zamieszczane przez różnych autorów na łamach kwartalnika „Młodzież - Kultura - Wieś. Polski Uniwersytet Ludowy" - czasopisma wydawanego przez Towarzystwo Uniwersytetów Ludowych (dalej też jako TUL) i stanowiącego od lat de facto jedyny periodyk nawiązujący ideowo do pedagogi(k)i Ignacego Solarza i bazujących na niej współcześnie podmiotów edukacyjnych.

Wyboru tekstów do omawianej tu antologii dokonał, co warto zauważyć, Jan Socha (ur. 1929) - znany i doświadczony dziennikarz zajmujący się problematyką wsi i rolnictwa, socjolog polityki (doktorat), od ponad dwóch dekad członek zespołu redakcyjnego TUL-owskiego kwartalnika, jeden z nestorów dziennikarstwa wiejskiego oraz środowiska samego Towarzystwa. Podkreślmy, że redaktor dokonał selekcji artykułów w sposób ciekawy i przemyślany, co pozwoliło na przekrojowe ukazanie wiodących wątków tematycznych, jakie pojawiły się w kilkudziesięciu numerach pisma, które ukazywały się w kolejnych latach III Rzeczypospolitej. Szkoda jedynie, że pod każdym z wybranych do tomu materiałów nie odnotowano, z którego numeru czasopisma on pochodzi. Ułatwiłoby to czytelnikowi pełniejszą recepcję całości, albowiem ten sam co do treści tekst, w zależności od tego czy był pi- 
sany w początkach transformacji, tuż po 1989 roku, czy też w np. 2010 roku uzyskać może - co oczywiste - diametralnie inną wymowę.

Całość wchodzącego w skład książki materiału została zestawiona w sześciu odrębnych rozdziałach.

Na rozdział I (zatytułowany: „Drodzy Czytelnicy! Idziemy do Was z sercem, co nigdy nie zawodzi”, co jest parafrazą znanej TUL-owskiej pieśni) składa się wybór blisko dwudziestu odredakcyjnych artykułów wstępnych z lat 1989-2012, co interesująco pokazuje czytelnikom, jak zmieniało się w tym okresie zarówno życie społeczno-polityczne w kraju, jak również kwestie, które we wskazanym okresie bywały zdaniem - redakcji „Polskiego Uniwersytetu Ludowego" - ważne dla polskich środowisk wiejskich oraz środowisk skupionych w TUL.

W rozdziale II (pt. „Zapisana w «PUL» wieś niespokojna”) znajdujemy osiem tekstów na temat procesów modernizacyjnych polskiej wsi oraz przemian w dążeniach, aspiracjach i ambicjach młodzieży wiejskiej zachodzących w ich efekcie. Z perspektywy lat szczególnie cennym artykułem w tej części książki wydaje się szkic Jana Szczepańskiego „Młodzież wiejska w życiu państwa i narodu" (s. 5-61).

Kolejny rozdział, trzeci, został poświęcony wybitnym postaciom z historii uniwersytetów ludowych. Rozpoczyna go szkic o „Ojcu-Założycielu” światowego ruchu UL - Mikołaju Grundtvigu. Dalej znajdziemy w nim kilkustronicowe szkice między innymi o Jadwidze Dziubińskiej, ks. Antonim Ludwiczaku, Ignacym Solarzu czy animatorach polskiego ruchu UL-owskiego po II wojnie światowej, takich jak: Feliks Popławski, Karol Małłek, Waldemar Babinicz i inni. To niewątpliwie wartościowy przegląd życia i dorobku osób bezpośrednio zaangażowanych w działalność internatowych uniwersytetów wiejskich w naszym kraju (choć zapewne nieco szkoda, że redaktor tomu nie pokusił się o skorygowanie niektórych wyraźnie błędnych informacji, o szczegółach życia czy poglądach takich postaci jak np. Grundtvig, Solarz czy Józef Kret podawanych przez poszczególnych autorów w tekstach pierwotnych, które zaczerpnął z łam kwartalnika „PUL”, a w kilku przypadkach także $z$ innych źródeł - głównie stron internetowych; może to bowiem doprowadzić do utrwalenia się tych nieścisłości wśród czytelników publikacji).

Czwartą część publikacji (pt. „UL-e w zwierciadle publikacji”) poświęcono prezentacji dwunastu artykułów z różnych lat, reprezentatywnie dla kwartalnika pokazują szanse i perspektywy uniwersytetów ludowych na przełomie XX i XXI wieku i w dalszej przyszłości. Zwłaszcza zawarte w rozdziale refleksje Tadeusza Pilcha, Zofii Kaczor-Jędrzyckiej, Hansa Hovenber- 
ga czy Bronisława Gołębiowskiego należą bezsprzecznie do najciekawszych fragmentów całej książki.

Z kolei rozdział V (pt. „Wieści prosto z UL-a”) zawiera przegląd inicjatyw (przedsięwzięć artystycznych, sesji popularno-naukowych, działalności warsztatowej itp.) podejmowanych w łonie Towarzystwa Uniwersytetów Ludowych po 1989 roku oraz środowisk i postaci je organizujących (m.in. Sławomira Konarzewskiego, Gabrieli Grzegorskiej, Zofii Kaczor-Jędrzyckiej, Elżbiety Gniazdowskiej). Całość stanowi zatem interesujący wybór ilustracji do historii Towarzystwa Uniwersytetów Ludowych w ostatnich dwóch dekadach.

Całość uzupełnia niezbyt obszerny ostatni rozdział (pt. „Szerokie horyzonty"), w którym zamieszczono pięć niezbyt obszernych szkiców oraz dwa wywiady ilustrujące, że na łamach kwartalnika „Polski Uniwersytet Ludowy” poruszana bywała również problematyka natury ogólniejszej (np. „Jan Paweł II o człowieku i kulturze” czy „Ludzie i wynalazki XX wieku”. Takie umiejscowienie w strukturze całości książki tych materiałów nie do końca jednak przekonuje. Wydaje się, że można było rozważyć połączenie tej części antologii z częścią pierwszą, która również miała charakter bardziej ogólny.

I przed zakończeniem jeszcze jedna delikatna kwestia. Otóż Jan Socha odnotował w „Słowie wstępnym”, że mimo iż „książka ma autorstwo zbiorowe”, to jednak ,jest jednocześnie pozycją autorską, zrodził ją mój pomysł, ja ją skomponowałem i zredagowałem, napisałem znaczną część zawartych w książce tekstów" (s. 5). To fakt, aczkolwiek wydaje się, że należało głębiej zastanowić się, czy jest to dostateczny tytuł do zapisu - zamieszczonego zarówno na okładce, jak i na stronie tytułowej publikacji - wyraźnie sugerującego, że jest to nie antologia tekstów różnych osób a książka autorska. Zapewne przynajmniej niektórzy czytelnicy odpowiedzieliby, że niestety nie.

Podsumowując niniejsze omówienie należy podkreślić, że dzięki staraniom zarówno samego Jana Sochy, jak i wymienionych na wstępie podmiotów instytucjonalnych otrzymaliśmy - mimo kilku uwag - unikalną publikację książkową dokumentującą ostatnie dwadzieścia parę lat działalności zasłużonego dla propagowania pieknej grundtvigiańsko-solarzowej idei i koncepcji nieformalnej edukacji dorosłych na obszarach wiejskich w Polsce Towarzystwa Uniwersytetów Ludowych oraz związanego z nim nierozłącznie czasopisma.

Tomasz Maliszewski 